Article

\title{
Rediscovering the Idea of Cultural Heritage and the Relationship with Nature: Four Schools of Essential Thought of the Ancient Han Chinese
}

\author{
Otto Chen * ${ }^{(1)}$ and Dawei Han \\ Department of Civil Engineering, University of Bristol, Bristol BS8 1TR, UK \\ * Correspondence: otto.chen@bristol.ac.uk; Tel.: +44-117-903-5428
}

Received: 12 June 2019; Accepted: 28 June 2019; Published: 3 July 2019

\begin{abstract}
After a long-standing debate of pluralism in heritage conservation, the global practice has just started to broaden its view from material to people and even to nature, leading to the potential of a more comprehensive understanding and harmony between these spheres. Notwithstanding that the shift from material to people and then to nature seemingly looks like the only path in the modern heritage conservation movement to achieve the foregoing goals, in fact, there exist some regional cultures that originally featured particular views on human-nature harmony. This paper hence highlights the regional difference in heritage with a focus on China of ancient times, which unfolds the particular perspective emphasising the unity of human and nature. With a case study of Huaqing Palace of the Tang Dynasty (618-907 CE), the research is expected to be the first attempt to rediscover that the four schools of thought, Buddhism, Taoism, Confucianism and I Ching, had jointly formed a "wisdom" system of the ancient Han Chinese in shaping the idea of cultural heritage, as well as the idea of heritage conservation, which were inherited by modern Chinese without knowing and recognising it. The paper, therefore, argues that without understanding and acknowledging the significance of the ancient Han Chinese's particular view on nature and the universe formed by the four schools of thought behind the material, it is not likely to protect and promote comprehensively their heritage value, such that the importance of cultural diversity will be just rhetoric.
\end{abstract}

Keywords: Chinese cultural heritage; heritage discourse; intangible; resilience; sustainability; tangible

\section{Introduction}

In recent developments, heritage conservation has been considered and highlighted as a process of management of change [1]; furthermore, many scholars have indicated that the value of cultural heritage has no longer been deemed to be immutable [2-5]. Given that management of change has become the main theme of heritage conservation, yet the current debate centres on the matter of what is allowed to change and what is not in conservation [1,2], therefore, the authors consider that understanding the relationship between change and cultural heritage prior to the current debate is essential. The ancient Han Chinese culture always emphasised the philosophy of change [6-9], which inspired the authors to conduct this research. The exploration can help understand the views of the ancient Chinese on change, as well as the relationship with cultural heritage, which can additionally promote the practice of regional pluralism in heritage conservation.

The dichotomy between heritage, people and nature in heritage conservation has long been criticised. With the tendency to focus on the material at the beginning stage of modern heritage conservation, it has led to overlooking the significance of the people aspect $[10,11]$. Notwithstanding that the later development highlights the engagement of the community, it has yet to pay much attention to something behind the community $[5,11]$, namely context. On the other hand, the division 
between nature and culture is a sustained issue and concern in heritage conservation [12,13]. In recent years, due to the emergence of non-Western conservation perspectives, as well as the advocacy of pluralism in conservation, the connections between nature, heritage and people have gradually been regained $[12,14,15]$. As such, the process of the development of modern heritage conservation can be understood as starting from heritage, then with the inclusion of people and eventually to the inclusion of nature, for achieving comprehensiveness and harmony in understanding and conservation. However, for achieving this goal, the process is not necessary and universal for many, as there exist many regional cultures known for the feature that places nature as the core in their cultures, as was the case in China in ancient times [16-18], as well as in indigenous communities [5,10,19]. In the modern movement of heritage conservation, modern China is eager to catch up with the step that is dominated by Western European counties with the process of development as such, whilst somehow, the Chinese forget what they have inherited from the past: the core idea and values of harmony between nature, people and culture, which might have been misplaced in the understanding of cultural heritage and heritage conservation. Therefore, through rediscovering the idea of cultural heritage and the relationship with nature in China of ancient times, this research seeks to regain the wisdom and provide a more advanced understanding of the past with respect to cultural heritage, which additionally echoes the principle of cultural pluralism in conservation.

In addition, when we compare the ternary discourses observed by Ashworth $([20,21]$, discussed in Section 4.2) with the attributes from the idea of cultural heritage of China of ancient times, it is interesting to note that many of the ideas and values regarding Chinese cultural heritage that are based on the core theme of change and harmony are parallel to the latest developed discourse of Ashworth shaped by the West. This is puzzling, as people expect that more understanding of regional culture should reflect more distinction, in particular between the East and West. Therefore, does this coincidence mean anything? The additional finding might yield inspiration to further exploration in the philosophical sphere of heritage studies in the future.

Therefore, this study argues that Chinese cultural heritage features not only abundant elements revolving around nature, but also considering change and harmony as a core concept, which provides some ideas that can benefit the development of managing change in heritage conservation. It is therefore of merit to rediscover what is the ideology behind the material. As for the research methodology, Merriam [22] pointed out that case studies are useful in qualitative research that aims to bring understanding and meaning to a phenomenon or an abstract idea. Johansson [23] indicated that a common understanding is that "a case is a phenomenon specific to time and space" and "a case may change over time, as well as its boundaries". Moreover, according to Yin [24], the case study method is suitable for answering research questions that ask "how" and "why", where the researcher wants to discover or explain a phenomenon; the method is useful when the context is important, but the boundaries between the case and the context are unclear. Yin also stressed that the case should focus on contemporary cases, whilst Johansson [23] argued that within the research field of architecture and planning, where artefacts are often studied, the distinction between contemporary and historical studies is of less importance. Johansson further stressed that "the context of design and the context of use may be separated in time, but are often equally important to the understanding of the case of an artefact". This research hence uses a water heritage, Huaqing Palace of Tang (723-755 CE), as the case study to investigate the influence of the four ancient thoughts from the material of heritage so as to rediscover the idea of the cultural heritage of the ancient Chinese. The data used consisted of historical literature, site observation, archaeological reports, planning documents and interviews with museum staff. Meanwhile, with the assistance of interviews with tourists/visitors of the study site, the common impression of linking the four ancient thoughts with the idea of cultural heritage also provides inspiration and manifestation of this rediscovery. The historical formation of the palace and the way of using natural resources, the hot spring, offer a window to see how the bathing culture and its physical infrastructure were endowed with the four schools of Chinese thoughts, namely Buddhism, Taoism, Confucianism and I Ching, with respect to the views towards nature, body and 
spirit. The research then provides a critical review of the four schools of thought by showing how the ideology and values forged the nature of Chinese cultural heritage and explores how the four schools of thought shaped the idea of cultural heritage and heritage conservation in China of ancient times. The findings regarding the core theme, harmony in change, are expected to provide a different lens for the management of change in heritage conservation.

\section{Debates of the Current Global Heritage Conservation}

\subsection{Divisions between Material, People and Nature}

The theory and practice of the modern heritage conservation movement was originated in Europe in the $19^{\text {th }}$ Century. Due to a large number of monuments and historical buildings damaged by vandalism and wars, the repair and restoration demands prompted the rise of heritage conservation. Under the context that monuments and historical architectures were the primary targets to be conserved at the early stage of the development of heritage conservation, heritage conservation not only developed into an independent domain of knowledge, but also with main concern for the physical part of heritage [25]. The understanding of cultural heritage value consequently tended toward historical, artistic and scientific values that could more readily reflect the material. Including the influence from international practice, i.e., World Heritage Convention and charters, the issue of reification (i.e., focusing on the material), along with the related issue of division between people (i.e., living community), nature and the material have been criticised in the recent decades [3,12]. As Taylor and Lennon noted:

Inherent in the pre-1990s global view of heritage was some division, and hence tension, between cultural and natural heritage conservation. Cultural heritage residing mainly in great monuments and sites was divorced from scientific ideas of nature and wilderness as something separate from people, an ideal seen in the extreme wilderness ethic. [13]

The division between culture and nature did not incur much debate at the earlier stage of the development. However, in recent decades, it has led to perpetual disputes, particularly from Asia Pacific, where there is abundant indigenous cultural heritage, such as Australia [3,14,26-29]. In global heritage conservation, one can often see that real cases involving indigenous heritage do reveal special views on nature and the universe, whilst their special values were once regarded as an "endemic example" and hardly had further exploration in understanding [27], as such indigenous heritage was usually excluded from global practice, namely the World Heritage system (i.e., WH hereinafter), as was described by Smith [3] as part of the authorised heritage discourse (AHD).

Due to the relevant debate, the World heritage system has been devoted to mitigating the issue of division between nature and culture, and it can be seen from two notable evolutions in the convention, as well as the advent of international charters, such as the Nara Document [30], which highlights spiritual and philosophical values from the living community and nature. As for the two important changes of the WH convention, one is that significant interactions between people and the natural environment have been recognized as "cultural landscapes" since 1992; the other is that the separated selection criteria of the cultural WH and natural WH were combined into one set of ten criteria to promote the inscription of the mixed properties since 2005. However, the performance is still rather unsatisfactory [13]. Taylor and Lennon investigated the improvement in this regard in World Heritage practice and noted some critical problems. They argued that although the merger of cultural-natural criteria in the World Heritage system has resulted in more "cultural landscape" and mixed site inscriptions of those assessed to have outstanding universal values, "there is still poor on-the-ground understanding of the management of all the integrated values expressed in the landscape". They also pointed out the inability to form multidisciplinary teams of state authority (including local authority) for the task of integrating the management of all values in the landscape, as well as the intentional or unintentional ignorance towards cultural and spiritual values for local communities. Furthermore, the separate administrations of the two advisory bodies-ICOMOS (International Council on Monuments and Sites) and IUCN (International Union for Conservation of 
Nature)—further compound the dichotomy, which "select experts for site assessment of nominations based on their specific discipline and then forwarding separate reports with their own disciplinary bias". The notes of Taylor and Lennon reveal that the dichotomy issue not only exists in the WH system, but also has become a general issue of global practice.

Through the prominent indigenous heritage cases all over the world, practitioners gradually recognised that it is of merit to put more effort into exploring the relationship between culture and nature and that there is no way to achieve comprehensive protection in heritage value without adequate understanding towards the nature aspect. However, ancient Chinese culture also featured particular views on nature and the universe; the significance of this sphere of ancient Chinese culture is by no means less than the significance to indigenous culture. This is puzzling, as little literature underlines this character in heritage conservation. The problem is more than the character being ignored; rather, it reflects a knowledge gap that modern Chinese may lack understanding in how the particular views on nature and universe significantly affect the formation and the idea of cultural heritage.

The WH convention in the recent past acknowledged two points from the experience of improvement:

At the conceptual level, there is a growing need to rethink natural and cultural heritage as an interrelated and interdependent concept, rather than as separate domains. At the management level, there is a need to rethink current approaches, where nature and culture management remain separate. [31]

The passage reflects exactly what this research seeks to achieve. The issue is also related to the activities carried out in the last two decades for safeguarding intangible heritage and the advent of the 2003 UNESCO convention. However, despite the substantial contribution to the conservation practice within the convention, it has yet to have an adequate influence on the WH system in terms of the issue of divisions between material, people and nature, as well as of inadequate attention in the intangible sphere. Therefore, to rethink natural and cultural heritage as an interrelated and interdependent concept, the research that rediscovers the harmony idea in Chinese of ancient times is regarded as the foundation for further developing new management approaches highlighting the inclusion of nature, heritage and context, which has been presented by the authors in another relevant research work [32].

\subsection{Universalization vs. Pluralism}

In addition to the debate over the dichotomy of culture and nature, the current global practice has also incurred other issues, such as the excessive emphasis on "authenticity", neglecting an intangible element, bias in favour of aesthetic value, preference for authority's or elites' values and overlooking community's rights and engagement. Most of these issues were described as AHD by Smith; it is noticeable that these issues are interrelated and that the causes of these issues reflect an inextricable connection with the material world [3]. More importantly, there exists a tendency of universalization in the current global heritage conservation, which makes these issues or AHD even more ubiquitous worldwide.

The universalization of conservation theory has shown some inapplicability in some regions, particularly in Asia Pacific. The "difference discourse" that underlines regional pluralism in conservation theory has been widely discussed in the past two decades. There are a number of examples in East and South Asia addressing the issue of authenticity, which is mostly attributed to architecture types that mainly apply timber structures. The architectures feature having traditions of maintenance by replacing damaged timber or restoration procedures [14,33]. In the modern heritage conservation movement of China, despite the fact that the universalization has caused many disputes, such as the Qufu Declaration expressing the disagreement with certain conservation methods from international charters and concepts [34], it still dominates and drives the practice towards the direction of AHD [15,35-37]. Notwithstanding that China has been catching on with the listing of the forty World Cultural Heritages (till 2017), second only to Italy, as well as the achievement of establishing 
new charters, including China Principles, Shanghai Charter and Xi'an Declaration, many scholars and practitioners still dispute that these charters are not proposed with particular perspectives on comfort in the Chinese context, as the three charters still focus on the "curative" measures of physical heritage, and there seems something significant and particular still missing. There is even suspicion of reinforcement of the Athens and Venice Charter in order to ingratiate international organisations [38,39].

A number of experts have suggested that the cultural heritage in Asian is often more closely related to philosophical and religious thoughts, and it is hence necessary to put forward regional theory or perspectives of conservation in accordance with local thoughts and social context [40]. Taylor and Lennon [13] also noted that "central to discussions on heritage conservation in Asia ought to be recognition of the intangible value systems that traditional communities associate deeply with so-called natural areas as part of their cultural beliefs" and "human rights of Indigenous and local communities whose systems of looking at land and landscape will differ from western ideas embodied in World Heritage practice". A recent follow-up discussion was made by Akagawa [41] regarding Ise Shrine, which has become an iconic representative of an "Eastern approach" to heritage proposed from the discussion of the Nara Conference, arguing that its presentation and interpretation as a cultural site is devoid of its distinct religious and political significance, limiting what can be learned from it. He argued that without full recognition of the religious beliefs intimately embedded in the traditional social context, practices and attitudes related to built heritage, recognition of cultural diversity would remain limited, and the declaration in Nara Document [30] may be misconceived as merely a concession towards the standard of authenticity, as such a criticism towards the three Chinese international documents. Similarly, in the Chinese case, the authors hence argue that without understanding and acknowledging the significance of the ancient Chinese's particular view on nature and the universe related to philosophical and religious thoughts behind the material, it is not likely to protect and interpret comprehensively heritage value, not to mention to sustain pluralism in heritage conservation.

\section{Case Examined: Huaqing Palace of Tang}

In order to understand the presentation and influence of the particular cultural characteristics originating from the four schools of thought on Chinese cultural heritage, but also to explore the perspectives and attitudes of the Chinese of ancient times towards heritage conservation, a case study was hence carried out to help find the particular views of the Chinese of ancient times towards nature and heritage in this research. There are several reasons for selecting Huaqing Palace of Tang for the case studies instead of a traditional architecture. Firstly, Huaqing Palace covers the features of not only traditional architecture, but also its connection to nature through hot springs, as well as a minor role of the capital, which can better present particular cultural characteristics reflecting more aspects of heritage, the tangible and intangible sphere. Secondly, the site has experienced numerous changes in a very long period covering many dynasties and times, which places it in an adequate role to deduce some common views of the ancestors towards heritage conservation. Thirdly, it is a very important heritage in Chinese history, also one of the most well-known historic stories in Chinese culture. Notwithstanding that the physical heritage had been abandoned and covered after the Tang Dynasty for more than a thousand years, the heritage had still been living in the Chinese's minds for generations before the very late archaeological discovery in the $20^{\text {th }}$ Century. How could a historic story endlessly yield literature and artworks that also became heritage in later times, which perpetuate the story and Huaqing Palace? Does it reveal something special and distinct, in terms of the idea of how heritage is constituted and how heritage is passed on and interpreted?

\subsection{Development History}

Mt. Li, the Chinese emperors' favourite natural place with excellent Feng Shui conditions, is located in the east suburb of Xi'an where it used to be the capital Chang'an of thirteen dynasties (around 1200 years) of China of ancient times (Figure 1). The mountain features not only beautiful 
scenery as the royal garden of the imperial palace of the capital, but also the prestigious hot spring that has been considered by Chinese as the "best hot spring in the world".

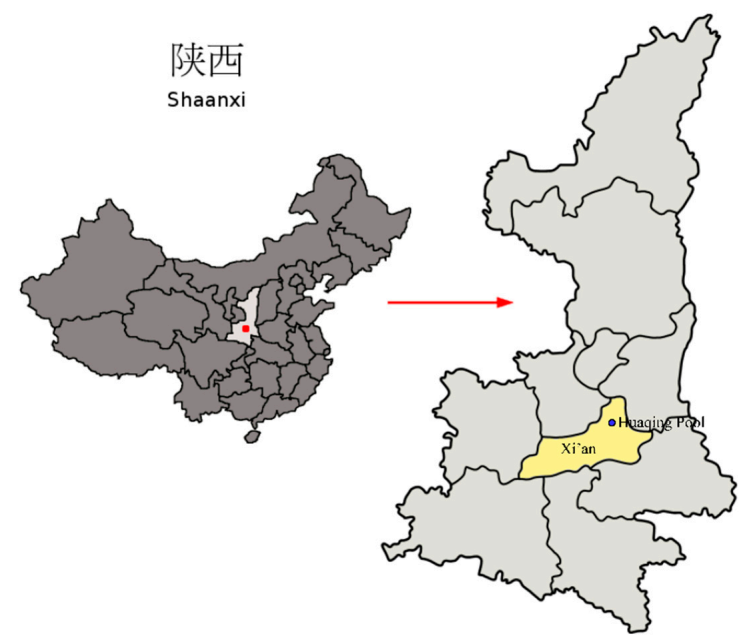

Figure 1. Location of Huaqing Palace. Source: based on Wikimedia "Xian".

The Mt. Li hot spring has been actively utilised since the Jiangzhai ancestors of the Mt. Li area, dating back some 6000 years to the Yangshao period (New Stone Age). With the spectacular scenery of $\mathrm{Mt}$. Li, the outstanding health value of the curative hot spring and the adjacent location to the capital, King You of Zhou (795-771 BCE) formally established the imperial exclusiveness of Mt. Li hot spring by building Stars Thermae as an imperial retreat at the place of the emergence of the hot springs, which is at the northwest foot of the mountain. Followed by Emperor Qin Shi Huang of Qin (259-210 BCE), Emperor Wu of Han (141-87 BCE), Emperor Wu of Northern Zhou (560-578 CE) and Emperor Wen of Sui (581-604 CE) respectively undertook significant restoration of the retreat. As the first ruler uniting China in $221 \mathrm{BCE}$, Emperor Qin Shi Huang adored Mt. Li hot spring for the enjoyment of his life and selected the north foot of the mountain where he built the mausoleum for his afterlife, ${ }^{1}$ which reflects the bond and attraction of the Mt. Li hot spring environment to the ancient Chinese royalty who regarded it as a propitious and sacred place for people to communicate with the universe and gods. Subsequently, two emperors during the Tang Dynasty undertook the most significant reconstruction on the site. In $644 \mathrm{CE}$, Emperor Taizong of Tang considerably reconstructed the retreat into a discrete palace and named it the Palace of Warm Thermae. Followed by Emperor Xuanzong of Tang in $723 \mathrm{CE}$, with the hot spring source as the pivot, he massively and extravagantly expanded the palace area into a miniature of the capital as his second/substitute palace and named it Huaqing Palace, a title that has been retained until the present day. Since the palace was specially built with hot spring baths, it was also called Huaqing Baths or Huaqing Pool [42].

Huaqing Palace of Tang (Figure 2) covered an area north of the Weihe River, south to Mt. Li, for $1.7 \mathrm{~km}$, with the terrain rising from north to south, and was enclosed on the east and west by Linshui River and Tongshui River, for $1.2 \mathrm{~km}$. The whole palace area was an enclosed piece of land encompassing three zones that were, from north to south, Zhao Ying County, the main palace, and Ban Court of Mt. Li. Zhao Ying County was arranged as a miniature of the cityscape of the capital Chang'an, mainly for the residence of the government officials and royalty; the main palace functioned as the palace of the capital; Ban Court of Mt. Li was a huge royal garden with numerous religious and entertainment facilities.

According to the records, from 712-755 CE of his reign, almost every winter, the emperor relocated to Huaqing Palace with his consort Yang (one of the four historic beauties of the ancient Chinese).

1 The Mausoleum of Qin Shi Huang, Eighth Wonder of the World, World Heritage. 
The emperor and Yang enjoyed the pleasures of thermal bathing and a variety of entertainment there, before returning to the capital Chang'an in the late spring of the following year. It was in this period that Huaqing Palace reached its historic height of power and splendours [42].

Whilst Emperor Xuanzong was busy seeking romantic pleasures and ignoring government affairs, as a result, the powerful Tang Empire began to fall. Huaqing Palace was extensively destroyed in the subsequent rebellion war $^{2}$ and was abandoned and lay ruined throughout the Song, Yuan, Ming and Qing dynasties for around a thousand years. Notwithstanding that the ruins had been buried underground and hidden for centuries, the existence of Huaqing Palace and its well-known stories had always been stayed in people's minds (i.e., the extreme enjoyment with the most beautiful lady leading to the fall of the Tang regime). Since 1949 and the advent of a new non-monarchy era, the People's Republic of China, sections of the Huaqing Palace have been reconstructed as a memento above the ruins covered, in accordance with the historical documents of Tang, and expanded several times to the present scale, albeit still less than one-tenth of the original palace of Tang. Since then, the reconstructed palace has become a popular tourist spot, listed as a $5 \mathrm{~A}$ scenic area by the Chinese government (i.e., the highest level of tourist attractions in the rating categories used in the People's Republic of China). In 1982, during a tourism construction project in the reconstructed palace, the famed and mysterious ruins of Tang were unexpectedly discovered, recognised as the most important archaeology discovery of Tang. Soon after, the site was designated as a "Major Historical and Cultural Site Protected at the National Level" by the Chinese government.

\subsection{Presentations of the Four Schools of Thought on the Material}

In 1982, during a tourism improvement construction project in the reconstructed Huaqing Palace, the famed heritage of Tang was unexpectedly discovered. Afterwards, several archaeological excavations were sequentially carried out, the outcome of the whole task considered as the most significant discovery of the Tang Dynasty to date. The discovery finally manifested the existence of the great Huaqing Palace of Tang. Through the re-examination of the cultural characteristics of the archaeological findings, this section attempts to unfold the particular view towards nature behind the physical sphere of the heritage.

The first excavation uncovered Stars Thermae of Tang and the previous cultural layers of Qin and Han [43]. Stars Thermae was the hot spring bath used by Emperor Xuanzon's ancestors, including Emperor Taizong of Tang, Gaozong of Tang and many other former emperors of Tang. After Emperor Xuanzong of Tang built his Lotus Thermae, Stars Thermae was no longer used by the emperor, but was used as a reservoir to supply the other baths. The new role of Stars Thermae implies the monarch's love and generosity in sharing the god-sent gift with his people. It also reveals that the purpose of showing respect to the heritage pool that features divine communication between the ancestors and gods through the god-sent hot springs constitutes the idea of heritage conservation.

The 1983-1986, excavations basically confirmed five thermaes of Tang encompassing Lotus Thermae, Begonia Thermae (for consort Yang), Prince Thermae, Shangshi Thermae (for close officials) and Yichun Thermae (for maids in the palace), as well as two unspecified thermaes built before the Tang Dynasty [44]. Then, the 1988-1990 excavations confirmed the existence of the Mt. Li Thermae of Qin and Han beneath the Tang layer [45]. The 1995 excavation continued to explore Pear Orchard and its Small Thermae of Tang where Emperor Xuanzong and Yang trained talented opera and musical performers [46], which played an important role in the development of Chinese opera culture.

This research re-examines the archaeological findings of Huaqing Palace of Tang, through a different lens that focuses on elements of the material revolving around nature to unfold the view of the

2 The An Lushan Rebellion was a devastating rebellion against the Tang regime, which caused emperor Xuanzong to flee to a sanctuary of Sichuan; in the meantime, he was forced to order the strangling of consort Yang, due to the blame from the emperor's bodyguard troops on her family for exposing the whole country to danger. 
four schools of thought towards nature. The data obtained and analysed by the authors through site observation and review of archaeological reports [43-47] is summarised as follows (see Appendix A Table A1 for the analysed data),

I. The overall layout of the Tang Huaqing Palace, including the three main areas, explicitly followed the framework of the capital Chang'an. It illustrates the Confucian thinking of the "happy/golden mean" through the principle of the central axis and symmetry, implying that balance and fairness in personality and behaviour facilitate harmony in society [48]. On the other hand, the layout of the whole palace area enclosed by the three rivers and Mt. Li demonstrates a typical Feng Shui principle of site selection that is believed to bring harmony and prosperity to people and the environment (Figure 2) [49].

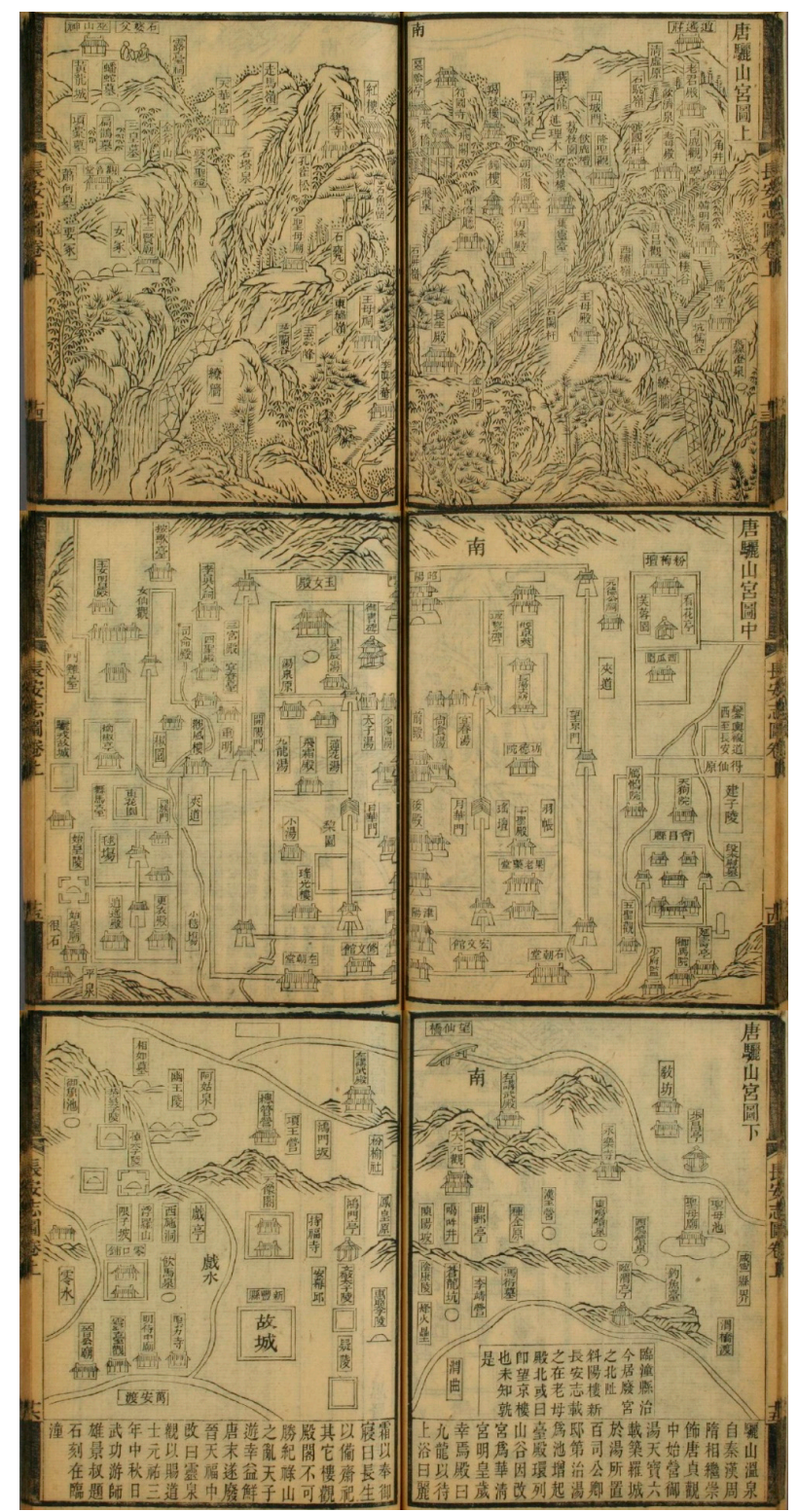

Figure 2. The map of Mt. Li palace of Tang according to You Shixiong of Song. Source: [50]. The upper part (south) shows Ban Court of Mt. Li; the middle part shows the main palace that followed the principle of symmetry, based on the thought of Confucianism. The lower part shows Zhao Ying County (further north). All three areas are surrounded by Mt. Li and two rivers, reflecting the great use of the Feng Shui principle for site selection of the palace. 
II. Notwithstanding the arrangement of the bath buildings not seeming to follow Feng Shui strictly in terms of the principle of the layout of the architecture complex, it demonstrates the rooted sense of Confucian in terms of hierarchy. By locating the thermae of the user with higher status closer to the hot spring source to show their priority to enjoy the hot springs, the respect between different roles and statuses facilitates harmonious relationships. For example, Stars Thermae (for passed emperors) supplied water to Prince Thermae, Shangshi Thermae (for use of close officials) and Yichun Thermae (for use of maids), whilst Lotus Thermae (for Emperor Xuanzong) supplied water to Begonia Thermae (for consort Yang).

III. The idea of the "learning from nature" of Taoism apparently is reflected everywhere in the pools of Tang, including the materials, engineering methods and decorations. The wall and floor of the bath pools were constructed and cemented with a multi-layered method and nature-based materials for waterproofing. Instead of applying metal (i.e., lead sheets) to waterproof as the Romans often did [51], the baths of Tang in the site were consistently constructed with masonry as the surface layer and with cord-patterned brick and rammed earth as the waterproofing layer, which are all related to the Earth. The use of pottery pipes between pools is another example showing the lack of use of metal; as the Chinese of ancient times considered metal as an unnatural material such that they hardly applied it in the structure of residential architecture, not even with one metal nail or bracing [52]. Moreover, the sophisticated inlet and outlet of the baths also reveal the intention of highlighting naturalness. Instead of using an open channel inlet by overflow, the inlet of Tang baths was particularly set at the bottom of the pool with the connection of male-female pottery pipes, designed as a hydraulic pressure tube set underground, so that hot springs gushed from the bottom. Furthermore, the design of the outlet and the water level control of the Tang pools also elegantly follows the principle of naturalness. Instead of using an open channel outlet by overflow, the designer set the drain hole at the bottom and connected it by an underground pipe to an open channel. This open channel, with a moveable weir plate, was used as the vessel for controlling the water level. This special and ingenious inlet and outlet system not only created a good thermal convection that enhanced the temperature uniformity and comfort, but also produced a nature-like gush of hot spring water from the bottom, which created a similar condition to a natural hot spring pond and reconstructed the sense of naturalness and value (Figure 3). Furthermore, the appearance of the design also highlights the naturalness by shaping and naming the pools after plants, as well as employing Bagua ${ }^{3}$ characters (Figure 4).

\subsection{Intangible Heritages Involved}

It is worth discussing the associated cultures of Huaqing Baths because they can also help understand how the four schools of thought shape Chinese cultural heritage. The significant cultures behind Huaqing Palace feature a combination of the bathing culture and the hot springs culture of the Chinese of ancient times. The bathing culture can be generalised into three aspects in terms of demand, including the health needs of daily life, the demands of social etiquette, and the influence of religion, whilst the hot springs culture reveals how the ancient Chinese viewed nature.

In terms of daily life, bathing had developed into a custom of good habits and manners since the Qin Dynasty (221-206 BCE): washing the head every three days and washing the body every five days, ruled in Liji (or the Book of Rites) and Yili (or the Book of Etiquette and Ceremonial) that are included as the Five Classics of Confucianism. In the Han Dynasty (206 to $220 \mathrm{CE}$ ), the law of "Xiu Mu" was established, ${ }^{4}$ which gave an official day off every five days to officials to take bath and change clothes [53]. Afterwards, the Chinese continued to regard bathing as an important thing in daily life.

3 Bagua are eight trigrams, and the fundamental principles of I Ching, also used by Taoist, to represent the movement of all natural phenomena. Bagua is also related to the Tai Chi philosophy and the Five Elements and applied in Feng Shui, cosmology, and astronomy.

4 Literally "a break for bathing". 
As recorded in Qing-su ji-wen, it was believed that bathing on "good days" would bring good fortune, so that people in the Ming and Qing period (1368-1912 CE) bathed on the basis of those good days and times listed in the traditional Chinese calendar [54]. It is recognised that the selection approach of the auspicious time and day listed in the calendar was developed with the principles of I Ching [55].

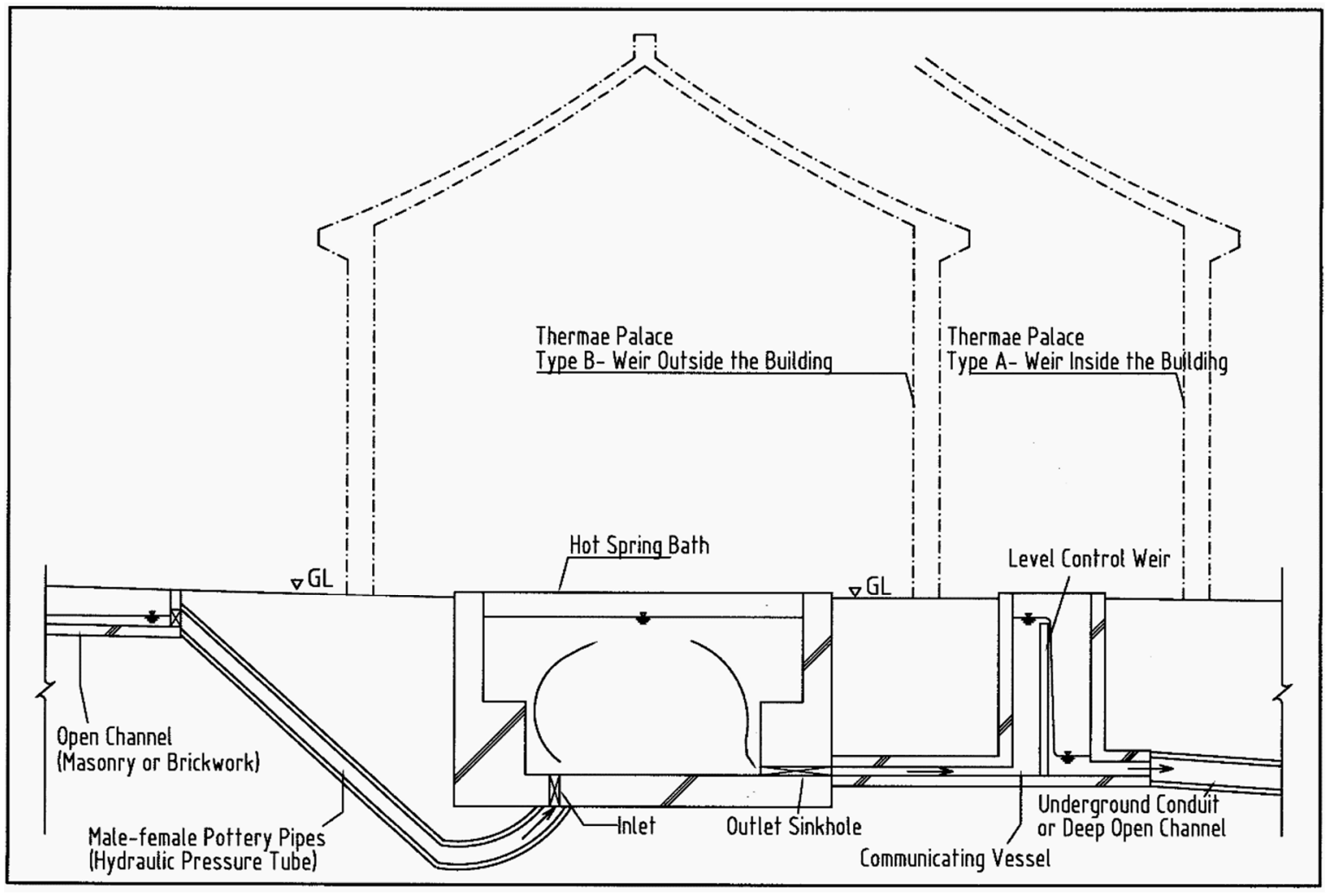

Figure 3. The inlet and outlet of the baths. Source: the authors.

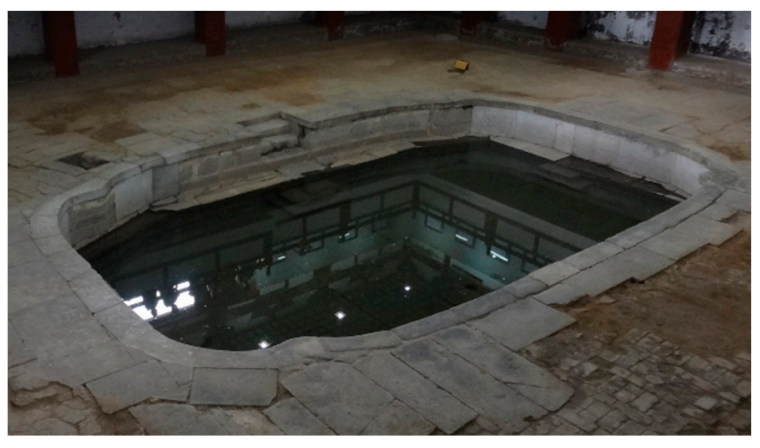

(a)

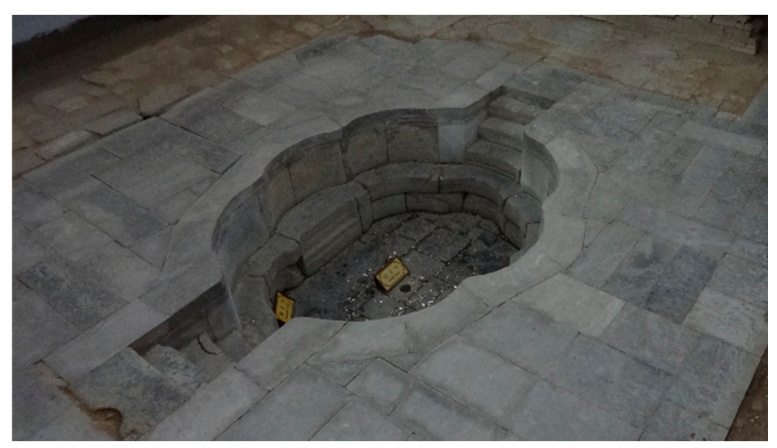

(b)

Figure 4. (a) Lotus Thermae (for the emperor). The lower part of the pool wall was made into the shape of an octagon, which represents Bagua, implying harmony of all aspects of the world. The upper part of the pool wall was made into the shape of a lotus, which is regarded as a sacred object in Buddhism, symbolising the purification and freedom of the soul. The photo demonstrates the special and exquisite outlet system, which employs Type A of Figure 3. Source: the authors. (b) Begonia Thermae. The photo demonstrates the special and exquisite outlet system, which employs Type B of Figure 3. Source: the authors.

As for social etiquette, "Confucians take a bath to purify moral" and "Confucius went to court after bathing" in Liji manifest how Confucius had been practicing what he preached about the bathing ritual. Since then, people who were going to participate in important activities, such as joining in 
celebrations or formal social occasions, receiving guests, etc., usually bathed beforehand as a spiritual self-purification and respectful practice.

As for the influence of religion, Taoism and Buddhism both believe water is cleansing and plays a vital role in expelling evils and providing spiritual purification, particularly in practicing their rites. Buddhism, in particular, has always advocated the importance of bathing, forming the monk's habit and rule of frequent bathing. Consequently, there were usually bath facilities in both Taoist and Buddhist temples during the Tang period when the religious activities were frequent and prosperous [56].

The idea of body privacy in bathing had also changed due to the influence of Taoism and Buddhism; notwithstanding that the Chinese religions usually represent constraint. In the earlier ancient Chinese ritual society, the Chinese took body privacy seriously and conservatively, which means generally no one would allow others to see her or his naked body, not to mention to share a hot springs bath with others. Even a man would prefer a private and exclusive bathroom rather than sharing with female family, recorded as a rule in Liji. Therefore, public bathing was once hardly acceptable, leading to the very late introduction of public bathing in the Song Dynasty (960-1279 CE). However, how was the conservative thinking changed? During the very prosperous time in religion in the Tang period (618-907 CE), Buddhist temples provided accommodation for travellers; in the Song period, temples even provided travellers and travelling monks with food, accommodation, and bathing facilities [56]. People of the time hence naturally rationalised the idea of public bathing from the shared bathing practices of the monks who considered the human body as merely a shell of the soul, parallel to any non-living things that are asexual, so that body privacy was not an issue when purifying the soul through bathing. This manifests an important idea of Buddhism that people should not cling to the physical world, including the body and objects.

The idea of being god sent also reveals how the Chinese of ancient times viewed nature. Hot springs had always been considered as a special gift from the gods, which makes water unusual; the places of the emergence of hot springs hence were considered as spaces where a human could propitiously communicate and harmonise with gods or the universe through contact with hot springs and the beneficial " $q i$ " therein. Consequently, with a strong sense of class and the divine right of emperors in ancient Chinese culture, most of the extraordinary hot spring resources were considered as being owned by an emperor, who was regarded as "the son of heaven". Many hot springs sites hence had been built as the monarch's holiday retreats, or sometimes even the second palace, which formed a special culture of discrete palaces among the hot spring culture.

The idea of balneotherapy ${ }^{5}$ of hot springs is a good example to elucidate the difference between the Chinese and the West regarding the views towards nature. The Chinese of ancient times believed the balneotherapy effect starts from mental to physical, whilst the Western idea is more from physical to mental. For instance, the Chinese hot springs were relatively simple because soaking without doing anything was essential, to reach the status of "emptiness" of Buddhism or to attain enlightenment of the harmony with nature to purify the bather's spirit, as the principle of Taoism. As a result, the body then can obtain a better cure from the quality of hot springs. On the contrary, the Romans believed the effect was formed by the combination of adequate exercise, different temperatures of bathing and even massage, through the various physical and sensory interventions to obtain body relaxation, so as to achieve eventually mental refreshment.

The hot spring bathing culture was often inevitably related to a luxury imperial palace and dissolute enjoyment. Emperor Taizong of Tang officially led his vassals to visit the Mt. Li hot spring after the construction of his discrete palace and showed his honoured inscription "Hot Spring Inscription", in order to reveal deliberately his hard efforts of managing government affairs beyond his fancy for the site with the mention of his suffering from rheumatism for years, amazingly cured by the hot springs [53]. The inscription also reveals his deep concern about his hot spring enjoyment,

5 The treatment of disease by bathing. 
incurring the impression of his pleasure-seeking and duty-neglecting attitude toward his people. Unfortunately, his descendant, Emperor Xuanzong of Tang, without learning from it, splendidly built Huaqing Palace for having ultimate enjoyment with his consort Yang, one of the four most beautiful and attractive women in China of ancient times, leading to the ignoring of government duty and eventually the fall of the Tang Empire. Huaqing Palace of Tang was abandoned and became a ruin thereafter for around nine centuries. What is interesting and puzzling here is that a place that has "the best hot spring in the world" and is renowned for the exclusive enjoyment of emperors had no longer made the later emperors yearn for it. Moreover, the abandoned palace has been kept alive incorporeally in the Chinese's minds by countless productions of poem, literature and paintings until now, revolving around the story of the romance that actually warns the world that people should not lose good will and responsibility for the pursuit of ultimate enjoyment and the material world. Notwithstanding that we do not know what is the reason that the emperors of the following centuries left the site abandoned, we can still sense that those texts and arts of warning should be of significant influence. Therefore, this case shows that what the later generations inherited from Huaqing Palace of Tang was not a heritage site, but rather, a pearl of wisdom from the imperishable warning story that will never disappear, like the ruins of the palace. This reflects something essential regarding the idea of the heritage of the ancient Chinese, that heritage is something to pass on wisdom to the next generations. It implies that people did not cling to the forms of heritage, as well as the status of the material, which also reflects the idea of the impermanence of the physical world in Buddhism.

\section{Four Schools of Thought}

The case study elucidates how Chinese cultural heritage, tangible and intangible, is profoundly influenced by the four schools of thought practiced in the daily life of the Chinese of ancient times, from plebeians to monarchs. Apart from further understanding the essential values or ideologies of the four schools of thought regarding nature and the universe that cover the cultural characteristics presented in the foregoing Huaqing case, this research also attempts to explore the ancient Chinese's idea of heritage, as well as the idea of heritage conservation.

\subsection{Four Schools of Thought Embedded in Cultural Heritage}

To protect the value of cultural heritage, one must have adequate understanding of the unique views and values of the Chinese of ancient times towards nature and the universe and acknowledge their significance in heritage conservation, as these not only have affected the way the ancient Chinese interacted with the natural environment, but also have reflected common values of the ancient people.

Chinese culture has been inheriting and developing for more than five thousand years. With a variety of cultural contents, four among them have been rooted as the foundation of people's lives. The four schools of thought not only have affected many aspects of life, but also jointly formed as a common value system of the people, as one can easily find in a cultural heritage example such as Huaqing Palace with the applications of these four schools of thought. In addition, the four schools of thought have a notable feature. The four schools of thought are seemingly distinct whilst some essential ideas among them are similar and supportive of each other, meaning they developed separately, but had an influence on each other [35]. Therefore, in some respects, such as the view on nature and the idea of heritage, the four schools of thought coexisted without conflict; as a result, they have formed the conditions for shaping common values in the ancient Chinese's minds. This feature, therefore, has had significant influence directly and explicitly on Chinese cultural heritage, ever since they were created in ancient times. The four schools of thought are Buddhism, Taoism, Confucianism and I Ching (also known as Classic of Changes). In view of the profound contents of the four schools of thought, this section only focuses on the most associated parts affecting Chinese cultural heritage. 


\subsubsection{Buddhism}

Buddhism is a religion that was introduced into China from ancient India (2 BCE), with the actual meaning of the teaching of the Buddha, rather than the worship towards god Buddha, which is hence more of a philosophy compared with other religions. Buddhism's main doctrine is to get rid of mental suffering and reincarnation through the awareness of the mind, emphasising impermanence and the absence of self and of the perceived world. The idea of impermanence underlines that the status of all things will not last forever and that things that exist will eventually disappear, which implies that clinging to the perceived world hinders uncovering wisdoms [57]. It highlights the harmony between the empty mind and the perceived world of the mind. These ideas seem to be profound and hard to understand, whilst they are fundamental to the perspective and attitude of how the ancient Chinese treated the material world. A common presentation can be seen in the high application of timber structures in traditional Chinese architecture [14,58,59]. As wood is considered as a living thing with life and death, as for human beings, this also implies habitations are supposed to be occupied for a limited period of time, just as the human body. Moreover, the renovation or restoration of an old building was often regarded as another "rebirth" or as a way of respecting ancestors or gods [38]. In contrast, stone was regarded as a lifeless material, and therefore, masonry was more used in non-residential structures such as tombs, monuments and bridges, taking advantage of its durable properties.

\subsubsection{Ching}

Another school of thought that is easier to associate with Chinese heritage is I Ching. I Ching is one of the most ancient classics in China and was honoured by Confucians as one of the must-study Five Classics. Similarly, Taoism borrowed some concepts from I Ching, including yin and yang ${ }^{6}$ and the Five Elements/Phases, to integrate into some essential concepts of Taoism. I Ching presents a primary view of the philosophy and cosmology of the ancient Chinese, in the interactions between all things of the universe. It is generally believed that its theory is based on the interactions of cosmic stars, which can be analogized to the concept of universal gravitation in astrophysics. It uses the alternating characteristics of yin and yang to describe the state of harmony and disharmony and of auspiciousness and inauspiciousness in all things in the world; it also uses the Five Elements (i.e., metal, wood, water, fire, and earth) that are mutually generative or destructive reciprocals to describe the characteristics of everything in the world represented by the influence of yin and yang. Notwithstanding that I Ching is mainly used for divination, its applications have extended to traditional Chinese philosophy, religion, medicine, astronomy, arithmetic, literature, music, art, military and martial arts, with modern applications such as the traditional Chinese calendar ${ }^{7}$, traditional folk therapy, Feng Shui, traditional Chinese medicine, fortune-telling, date selection, Tai Chi (i.e., supreme ultimate boxing) and qigong (i.e., life energy cultivation), which have all become important cultural heritage in Chinese society currently.

The emphasis on the concept of harmony/auspiciousness and disharmony/inauspiciousness presents the environment aspect, such as Feng Shui, which is a well-known knowledge for selecting a location to plan and build, including locating palaces, villages and cemeteries and planning architecture layouts. Based on I Ching, Feng Shui also highlights the harmony between human (including built environment), nature and the universe. It uses "q $i$ " to explain the state of the harmony between human and environment (built and natural), which is influenced by the motions of the cosmos and the changes of any other things (including human and environment) [60]. In the interaction with nature, as long as the movement of $q i$ is taken into consideration following the principle of harmony, the resident

6 Lit. "dark-bright", "negative-positive", which is used to describe how seemingly opposite or contrary forces may actually be complementary, interconnected and interdependent in the natural world, applied in I Ching and Taoism.

7 The Chinese calendar is a lunisolar calendar that organises years, months and days according to astronomical phenomena. It also contains a method to guide Chinese people in selecting the luckiest days for weddings, funerals, moving or setting up business, which was developed through the principles of I Ching. 
will naturally be benefitted by the auspiciousness state of the environment. Through the application of Feng Shui in locating, orientation, and layout planning, people can acquire such an ideal place of residence [61].

Feng Shui mainly contains two schools, namely Luan Tou Pai (i.e., Form School) and Liiqi Pai (i.e., Compass School; Figure 5a). The two schools are different in approach, whilst they are both based on the theory of I Ching; therefore, they do not contradict each other. The first school has strength in selecting terrain features of mountains and water, as well as the natural environment outside the building [62]. The principle is "back to yin and embraces yang" and "there must be $q i$ in a place where is surrounded by mountains and rivers" [49]; the condition of the surroundings of Huaqing Palace is such an example (Figure 2). Many principles of this school have been manifested by environmental and ecological science $[63,64]$. The other school claims that "humans thrive because of house, house exists because of human, both support each other and interact with the universe." The main approach is based on Bagua (i.e., eight trigrams) and astrology [64]; it is therefore difficult to explain its theory in a scientific way, whilst it can use "qi" (in analogy to invisible air current or energy) to help explain the influence on the occupant from the orientation and spatial layout of the building. The approach is to calculate and conjecture jointly according to the fate, temporal and spatial conditions to select the best location and layout of the building, including locating respectively the master's, elders' and children's rooms, hall, kitchen, toilet, water, drainage, and so on, and even to decide the dimensions of important structural components such as doors, windows, beams and columns (Figure 5b).

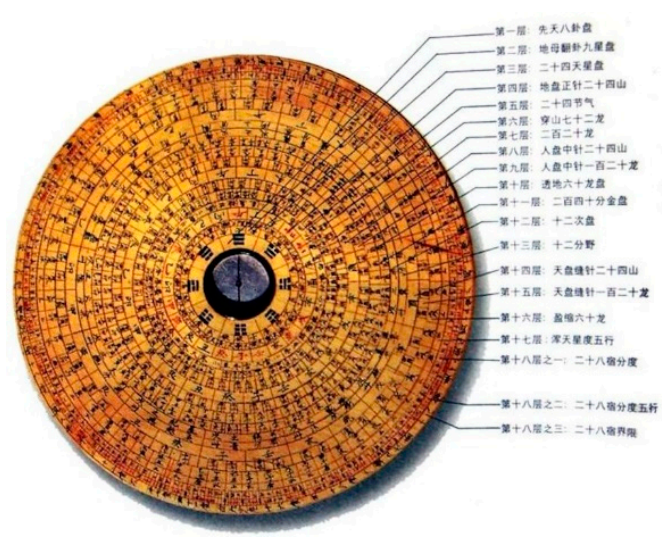

(a)

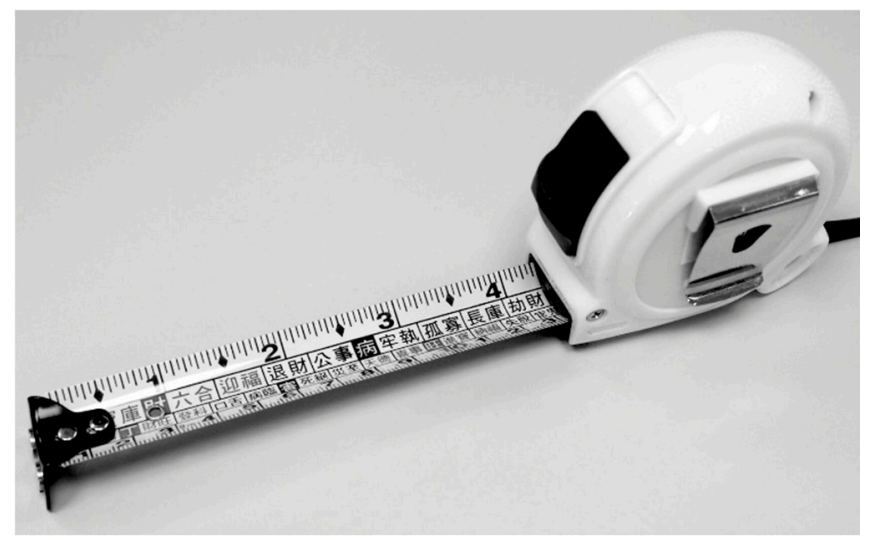

(b)

Figure 5. (a) Feng Shui compass. Source: Wikimedia "Feng Shui". The compass features applying Bagua principles; (b) Lu Ban ruler, made as a modern tape measure. Source: the authors. The Chinese words of the upper row show auspiciousness and inauspiciousness scales for the residence of living people, while the lower row of Chinese words are for the deceased.

\subsubsection{Confucianism}

Confucianism is a humanistic school of thought and philosophy founded by Confucius (551-479 $\mathrm{BCE}$ ). It is an active school of thought highlighting the self-cultivation of morality, emphasising that ren (i.e., humaneness) and $l i$ (i.e., etiquette and courtesy) complement each other to practice ethics so as to establish social harmony and good customs [65]. With harmony as the central concept [66], the ancient Chinese were influenced by Confucianism and had an active attitude of practice, presenting in many aspects of daily life. Confucianism considers complying with etiquette as the performance of intrinsic respect and benevolence to all things, including people, gods, nature and objects. Since everyone has different roles to play in society and family, in order to make society harmonious, compliance with etiquette helps play a good role in society. The $l i$ emphasises playing an appropriate and courteous role, rather than hierarchy or classification [66]. For example, a man may simultaneously play two roles, as a father and also as a son, which means he has different etiquettes to follow to treat his children 
and parents differently. It also prominently reflects in architecture; for instance, different forms of roofs, building heights and exterior colours all present different roles of the occupants. Not going beyond our own roles and proprieties to present a false status is an essential expression of respect to others [67]. The interior layout of a building or the layout of a building complex should be able to show the order of seniority or formality between young and old, male and female, host and guest and public and private, which is also a way of practicing courtesy. In addition, the concept of the "happy/golden mean", through the principle of the central axis and symmetry, is manifested in the layout of Chinese buildings, which preach balance and impartialness in individuals and society [48], as for the elucidation in the case of Huaqing (Figure 2). In terms of the architectural decorations, architectural paintings, porcelain ornaments, wood carvings and clay sculptures generally have the purpose of enlightenment of morality through the content of parables.

\subsubsection{Taoism}

Taoism is an ideology originating in China of ancient times and later developed into a religion. The main doctrine is the pursuit of naturalness, as well as the learning of truths and philosophy from nature, for the purpose of achieving the freedom of the mind [65]. As previously mentioned, Taoism contains the concepts of yin and yang and the Five Elements of I Ching, mainly for conceptualising one of the central concepts, harmony, towards the harmonious status of taiji (i.e., the origination of yin and yang) and wuji (i.e., limitless, ultimateless). The difference is that, instead of being regarded as profound and mentor-based knowledge as I Ching, Taoism facilitates and embodies the concept of yin-yang and the Five Elements through the understandable truth and phenomena of nature. For instance, it usually uses the characteristics of water, animals, and plants as metaphors or explanations. It has had a prominent influence on the design philosophy of Chinese traditional architecture and garden landscapes, which mainly brings naturalness and boundlessness into a limited built environment. For instance, by virtue of the attachment and longing for nature, traditional Chinese gardens try to present an infinite prospect of Taoism, the oneness/unity of nature and human, by bringing mountains, lakes or seas into a garden to make a garden a miniature of the boundless nature. By applying the principle of harmony between yin and yang, generative reciprocals of the Five Elements and learning from nature to design, Chinese architecture and gardens can therefore achieve a poetic prospect that is an enlightened, making it easy for people to perceive the "oneness/unity of nature and human" of the physical world.

\subsection{Presentations of the Four Schools of Thought on the Idea of Heritage and Heritage Conservation}

After understanding the particular view jointly formed by the four schools of thought towards nature and the universe, we can further explore how these four schools of thought shape the idea of heritage and of heritage conservation in China of ancient times.

Confucianism, Taoism and I Ching have a similar idea regarding tangible and intangible heritage, more precisely the tangible part and intangible part of heritage. The three schools of thought all consider the intangible part of heritage to be more important than the tangible part $[34,68]$. This is elucidated by the tao qi lun (i.e., discourse of tao and device; tao means the way and the truth of all things of the world, whilst the device means human-made stuff). The principle of "zhong tao qing qi" (i.e., emphasis on tao rather than on device) highlights that tao, including spirit, wisdom, knowledge, attitude, skill and manners that exist behind the human-made stuff, is what people should make effort to cherish and pursue. Based on the principle, it is notable that the ancient Chinese judged whether a heritage was of merit to maintain by judging what was the intangible part of the heritage (i.e., tao) and how important the tao was. This is different from what the modern values-based approach considers first: what is the value of the heritage, and how significant is the value?

The principle reflects numerous cases of the reconstruction of built heritage. The authenticity of the material of built heritage is hence considered as a relatively lower priority regarding heritage conservation of the ancient Chinese, whilst it does not mean that they did not consider authenticity as essential in heritage conservation. Confucianism highlights the necessity of the authenticity of 
literature, as it considers literature to be an essential form of wisdom of the author, which can be passed on to the generations forever. Therefore, shi jiao (i.e., education by poetry) is preached and plays an essential role in Confucianism, which has also substantially influenced the values of the ancient Chinese. A heritage (site) was considered of merit by generations usually due to the mentions in poems of sages [69]. Along with the authenticity of literature, Confucius also emphasised the importance of the living heritage community, who is the real witness and practitioner ${ }^{8}$ [68].

$\mathrm{Yu}$ indicated that the system of worship ceremonies and etiquette is the heritage conservation system of the ancient Chinese [68]. Supported by Confucianism, the system has lasted for more than four millennia since the Yin Dynasty, which underpins the foregoing principle of emphasising the intangible part of heritage. It is a system with official registration that features passing on from dynasty to dynasty, recorded by Liji (the chapter of Law of Sacrifices) and the Classic of History. The worship ceremonies and etiquette mainly encompass three categories, namely significant mountains and rivers, gods and ancestors (including sages). Among them, ancestor worship played a critical role in the conservation of built heritage, as a worship system and occasionally the order of the emperor officially stipulated the protection area of the tomb of sages, which is similar to the way the modern heritage conservation protects a site with a surrounding area in the planning and designation system [70].

The ancestor worship, along with the four schools of thoughts have also been embedded in Chinese traditional burial $[35,71]$. As Feng Shui also deals with the residence for the deceased and claims that the $q i$ between the deceased, the surrounding natural environment and the universe will influence the $q i$ between his/her descendants and the universe, as a result, the theory has become a belief of most of Chinese people, which perpetuates the burial culture. Consequently, the burial culture continuously reinforces the influence of the four schools of thought towards the past and heritage, generation by generation.

As the foregoing Section 4.1.2 revealed a critical point of Feng Shui theory, the change of occupant also means the change of $q i$. In other words, even though the surrounding environment looks unchanged, the $q i$ of a historical building is still subject to not only the continuous changing influence by the motion of the universe (temporal factor), but also to the change of the occupant (fate factor), leading to the changes of harmony/auspiciousness and disharmony/inauspiciousness in different times [72]. It is another influential feature regarding the idea of heritage conservation. It reflects the ancient Chinese's idea of heritage conservation and reuse towards historical buildings: the preservation of the intact physical state will not necessarily benefit the future occupant in terms of the Feng Shui condition the same the way as in the initial time; the later occupant tends to pursue the auspicious and harmonious status all over again by appropriate renovation and reconstruction in accordance to the updated application of Feng Shui. Another relevant reconstruction circumstance can often be seen, which is that ancient people reconstructed after the decay or destruction of a public built heritage that was originally created for the purpose of Feng Shui enhancement to a local area. In such a circumstance, Feng Shui acts as knowledge, as well as an intangible heritage itself to bring authenticity into the rebuilding of heritage in the present [35].

Zhang indicated that I Ching (and Feng Shui) may be understood as an ancient manifestation of sustainability due to many similarities between I Ching and the concept of modern sustainability [35]. Both I Ching and sustainability highlight the maintenance of harmony over time between people and nature as the central concept, on the basis of an ever-changing world and the universe. Moreover, the idea of sustainability from the four schools of thought also emphasises something that can always pass through future generations, which is noticeably wisdom: something is expected to be inherited from the past generation and something used to judge whether the tangible form of its bearer, which we call heritage, should be left and maintained.

8 Recorded in the Analects of Confucius, in which Confucius was describing that he was not able to manifest the etiquettes of the Xia Dynasty and of Yin Dynasty due to the lack of witnesses and practitioners. 
In the pursuit of harmony in the ever-changing world, the ancient Chinese also understood that disasters do happen sometimes. The idea of resilience is also presented in the four schools of thought, for instance as previously mentioned, shi jiao (i.e., education by poetry) and the system of worship ceremonies and etiquette are exactly the evidence of a system to avoid the eternal loss of wisdom, once disasters happen to the physical bearer. Another common example is zhang qao, basically a model rule used by the chief timber/carpenter craftsman (as the role of an architect in traditional architecture) to design and record the size of all the main beams, girders and rabbets as the basis for the construction. It was often stored on the roof truss after completion and could be easily applied in the future if restoration or renovation were necessary [73]. The example also reveals the idea of resilience to recover quickly from disasters or unavoidable changes.

The foregoing discussions manifest the authors' argument that harmony is the central concept of the four schools of thought, regardless of some different interpretations and entry points. The conceptualisation of heritage and the conservation of heritage both revolve around practicing the wisdom of the tao (i.e., the way and the truth of all things of the universe), in order to achieve sustainable harmony in the mental world (Buddhism), in family and society (Confucianism) and in the universe (Taoism and I Ching), which have jointly formed a common value system of the ancient Chinese that presents in cultural heritage and the idea of heritage and conservation. Harmony is the core idea of the four schools of thought, which comes with changes. Whenever changes happen, the wisdom is to pursue harmony. Whenever the harmony status alters, changes are unavoidable to pursue new harmony. Therefore, wisdom is something more likely to be sustained and the most important thing to be sustained through generations.

In the case study, how the Tang Dynasty used the pool of the former dynasty to integrate it into the building of the contemporary pool is exactly an applicable example of the wisdom of harmony, as well as the representation of the views towards heritage, which reside in the relation between nature (hot spring and the universe), heritage (the pool) and people. Furthermore, for the Tang Dynasty, the pools of the former dynasties were heritage, whilst for modern times, the pools of the Tang Dynasty are also heritage. This relativity shows that the principles of authenticity and integrity are characterised by the division of history into periods. In order to follow these two principles, the contemporary time needs to be frozen, so that change can be temporarily suspended, as Smith and Ashworth described in their discourses $[3,21]$. However, in fact, change is always occurring. This example of conservation and integration of the former pool in Huaqing Palace of Tang shows that whilst authenticity and integrity are important for heritage conservation, when the time scale is extended, change is natural and unavoidable. Therefore, what is more important is how to keep and present the contemporary ideas and wisdom towards harmony and heritage when change is happening. As such, this research rediscovers the ideas and wisdom of the past towards harmony and heritage, that the modern Chinese inherited without even knowing it.

Through the discussions of this research, the authors summarise the characteristics of the idea of heritage and the conservation of the ancient Chinese and compare it with Ashworth's ternary discourses of modern global practice, as shown in Table 1. However, it is very surprising to see that there are many parallels existing between the latest "heritage planning" discourse and the ancient Chinese "sustainability" discourse. As one can see, the evolution of the conceptualisation of heritage in the modern movement of heritage conservation is a shift from the perspective of science and technology to philosophy, as noted by Smith:

The dichotomy between tangible and intangible heritage needs re-thinking, and indeed, I posit all heritage is intangible. [3,10]

Notwithstanding that this additional finding of the coincidence between the perspective of modern conservation and the ancient Chinese perspective may need more evidence and discussion, the core theme of the finding, harmony between nature (including the universe), people (including the context) and the human-made world (becoming heritage in a later time), to accommodate changes, as well as the note of Smith in the last passage, both highlight a parallel idea that we should view and 
understand heritage from the intangible sphere, namely people, context and the bond with nature, and use harmony to connect the tangible and intangible sphere and to accommodate changes amongst them. The authors hence used this essential idea for further developing a new methodology with respect to the management of change in environmental management in another relevant research work [32].

Table 1. Characteristics of the heritage discourses, modern global practice vs. the ancient Chinese (compared with the ternary discourses of Ashworth [20,21]).

\begin{tabular}{|c|c|c|c|c|}
\hline & \multicolumn{3}{|c|}{ Ternary Discourses (of Ashworth) } & \multirow{2}{*}{$\begin{array}{c}\text { Chinese Discourse } \\
\text { Sustainability }\end{array}$} \\
\hline & Preservation & Conservation & Heritage Planning & \\
\hline Focus & Object & Ensemble & Narrative(s) & Harmony \\
\hline Goal & Protection & Adaptive Reuse & Use & Practice \\
\hline Justification & Value & Value/Reuse & Utility & Wisdom \\
\hline Criteria/values & Intrinsic & $\begin{array}{c}\text { Preserve } \\
\text { purposefully }\end{array}$ & Extrinsic & Extrinsic \\
\hline Authenticity of & Object & Compromise & Experience & Experience \\
\hline Change & Immutable & Adaptable & Flexible & Flexible \\
\hline Temporal Nature of Value & Static & Metastable & Dynamic & Impermanent \\
\hline Actors (who has authority) & Experts & $\begin{array}{l}\text { Policymakers } \\
\text { /Planners }\end{array}$ & Users & Users \\
\hline
\end{tabular}

\section{Conclusions}

By addressing the very fundamental and particular idea regarding the view on nature and heritage, the authors wished to draw more attention to the rediscovery of the perspective and values of the ancient Chinese. The finding highlights that harmony is the central concept of the four schools of Chinese thought that have influenced the conceptualisation, constitution and conservation of the cultural heritage of the ancient Chinese. As harmony is wisdom, using wisdom as a common language helps people understand the relationship of critical things and achieve consonance to sustain wisdom through the generations, especially in the general circumstance that values (system) can hardly be dogmatised by text, which is exactly the main challenge of the values-based theory and relevant approaches based on protecting value. The authors hence used the harmony perspective to underline the development of the methodology in managing change in related research, which features centring on the bond between heritage, context (i.e., people and something made by people) and nature and emphasising two essential aspects-sustainability and resilience- to accommodate changes.

Whilst practitioners debate what change is allowed and what change is not allowed for following the principle of authenticity and integrity, the finding of harmony also points out something significant prior to the debate, which is to understand why a heritage is kept until now and not abandoned over time when there was nothing like modern heritage conservation. In other words, it is the harmony that had always existed, so that there is no destructive change happening. To understand what the conditions of the context or the attributes of the heritage are to facilitate harmony, which results in survival, and what the changes that were experienced through different times and contexts were are in fact significant towards heritage conservation, as this is the very thing from the past, not a value given today, and we can really learn from it. In other words, rather than sticking to the debate of what and why something should be conserved, as the name of a book of Lowenthal and Binney [74] "Our past before us: why do we save it?", we should instead pay more attention to "why does it survive?", then we will discern the significance of harmony, as well as the essence of sustainability and resilience, which are the two very aspects the authors rediscovered here and highlighted in the proposed approach of the related research, no less essential than the value with respect to change.

Notwithstanding that such a view has long been rooted in the hearts of the Chinese, it has been mislaid in modern heritage conservation. It, therefore, should be recalled and acknowledged first, before a comprehensive understanding and protection of Chinese heritage value is achieved. The authors also wish that the limited finding could be an enlightenment to modern Chinese, who 
should resurrect the wisdom of "oneness of nature and human" of the past, as well as the inner nature of pursuing and practicing wisdom as the top priority of life, so that the everlasting pearls of wisdom will no longer be mislaid because of the pursuit of economic development.

Author Contributions: Writing, original draft preparation, C.O.; supervision, H.D.

Funding: This work was supported by the Institutional Links grant [332430681] under the Newton-Mosharafa Fund. The grant is funded by the UK Department of Business, Energy and Industrial Strategy (BEIS) and Egypt Science and Technology Development Fund (STDF) and delivered by the British Council. For further information, please visit www.newtonfund.ac.uk.

Acknowledgments: The authors give sincere gratitude to the reviewers of this paper, who have significantly guided the improvement of the content. Earnest thanks go to Jeremy Groome for his warm-hearted help in proofreading.

Conflicts of Interest: The authors declare no conflict of interest. 


\section{Appendix A}

Table A1. Water-related techniques applied in the baths excavated.

\begin{tabular}{|c|c|c|c|c|c|c|c|}
\hline Bath Name & User & $\begin{array}{c}\text { Construction } \\
\text { Period }\end{array}$ & $\begin{array}{l}\text { Pool Surface } \\
\text { Material }\end{array}$ & Outer Waterproof Layer & Inlet & Outlet & Other Features and Descriptions \\
\hline Stars Thermae & $\begin{array}{l}\text { Emperors before } \\
\text { Xuanzong of Tang }\end{array}$ & $\begin{array}{l}\text { The Western Zhou } \\
\text { Dynasty }\end{array}$ & Slate Masonry & $\begin{array}{l}\text { Wall: Cord-patterned Brick + } \\
\text { Stone Masonry } \\
\text { Bottom: Cord-patterned Brick } \\
\text { + Rammed Earth }\end{array}$ & $\begin{array}{l}\text { Male-female Pottery Pipes } \\
\text { beneath, Hot Spring Gushing } \\
\text { from the Bottom }\end{array}$ & $\begin{array}{l}\text { Masonry and Brickwork Open Channel, } \\
\text { with Slate Weir for Water Level Control }\end{array}$ & $\begin{array}{l}\text { - After the Construction of Lotus } \\
\text { Thermae, Stars Thermae Was Used } \\
\text { as a Reservoir, Supplying Water to } \\
\text { Prince Thermae, Shangshi Thermae and } \\
\text { Yichun Thermae } \\
\text { - Exhibition }\end{array}$ \\
\hline Lotus Thermae & $\begin{array}{c}\text { Emperor } \\
\text { Xuanzong of Tang }\end{array}$ & $\begin{array}{c}\text { Emperor } \\
\text { Xuanzong of Tang }\end{array}$ & Slate Masonry & $\begin{array}{l}\text { Wall: Cord-patterned Brick } \\
\text { Bottom: Rammed Earth }\end{array}$ & $\begin{array}{l}\text { Masonry and Brickwork } \\
\text { Conduit beneath, Hot Spring } \\
\text { Gushing from the Bottom }\end{array}$ & $\begin{array}{l}\text { Sinkhole at the Bottom of a Wall, Connected } \\
\text { with Underground Masonry Conduit, with } \\
\text { Slate Weir for Water Level Control }\end{array}$ & - Exhibition \\
\hline Begonia Thermae & Consort Yang & $\begin{array}{c}\text { Emperor } \\
\text { Xuanzong of Tang }\end{array}$ & Slate Masonry & $\begin{array}{l}\text { Wall: Cord-patterned Brick } \\
\text { Bottom: Rammed Earth }\end{array}$ & $\begin{array}{l}\text { Male-female Pottery Pipes } \\
\text { beneath, Hot Spring Gushing } \\
\text { from the Bottom }\end{array}$ & $\begin{array}{l}\text { Sinkhole at the Bottom of a Wall, Connected } \\
\text { with Underground Male-female Pottery } \\
\text { Pipes and Masonry Conduit, with Slate Weir } \\
\text { for Water Level Control }\end{array}$ & $\begin{array}{l}\text { - Exhibition } \\
\text { - The Water Was Supplied by } \\
\text { Lotus Thermae }\end{array}$ \\
\hline Prince Thermae & $\begin{array}{l}\text { Princes of Tang } \\
\text { from Emperor } \\
\text { Taizong to } \\
\text { Xuanzong }\end{array}$ & $\begin{array}{l}\text { Unknown, } \\
\text { Reconstruction } \\
\text { during Emperor } \\
\text { Taizong of Tang }\end{array}$ & Slate Masonry & $\begin{array}{l}\text { Wall: Cord-patterned Brick + } \\
\text { Stone Masonry } \\
\text { Bottom: Cord-patterned Brick } \\
\text { + Rammed Earth }\end{array}$ & $\begin{array}{l}\text { Male-female Pottery Pipes } \\
\text { beneath, Hot Spring Gushing } \\
\text { from the Bottom of a Wall }\end{array}$ & $\begin{array}{l}\text { Masonry Open Channel, with Slate Weir for } \\
\text { Water Level Control }\end{array}$ & $\begin{array}{l}\text { - Abandon during the Palace } \\
\text { Reconstruction of Xuanzong of Tang } \\
\text { - Serious Destruction } \\
\text { - Exhibition }\end{array}$ \\
\hline $\begin{array}{l}\text { Shangshi } \\
\text { Thermae }\end{array}$ & Close Officials & $\begin{array}{c}\text { Emperor } \\
\text { Xuanzong of Tang }\end{array}$ & Slate Masonry & Bottom: Rammed Earth & $\begin{array}{l}\text { Male-female Pottery Pipes } \\
\text { beneath, Hot Spring Gushing } \\
\text { from the Bottom }\end{array}$ & $\begin{array}{l}\text { Sinkhole at the Bottom of a Wall, Connected } \\
\text { with Underground Masonry Conduit, with } \\
\text { Slate Weir for Water Level Control }\end{array}$ & - Exhibition \\
\hline Yichun Thermae & $\begin{array}{l}\text { Women in the } \\
\text { Palace }\end{array}$ & $\begin{array}{c}\text { Emperor } \\
\text { Xuanzong of Tang }\end{array}$ & Slate Masonry & $\begin{array}{l}\text { Wall: Cord-patterned Brick } \\
\text { Bottom: Rammed Earth }\end{array}$ & $\begin{array}{c}\text { Male-female Pottery Pipes } \\
\text { beneath, Hot Spring Gushing } \\
\text { from the Bottom }\end{array}$ & Unknown & $\begin{array}{ll}\text { - } & \text { Serious Destruction } \\
\text { - } & \text { Backfill after Archaeology Excavation }\end{array}$ \\
\hline $\begin{array}{l}\text { No.1 Unknown } \\
\text { Thermae }\end{array}$ & Unknown & $\begin{array}{l}\text { Unknown, } \\
\text { probably as early } \\
\text { as Stars Thermae }\end{array}$ & Stone Masonry & $\begin{array}{l}\text { Wall: Stone Masonry } \\
\text { Bottom: Rammed Earth }\end{array}$ & Masonry Open Channel & $\begin{array}{l}\text { Brickwork Open Channel, with Slate Weir } \\
\text { for Water Level Control }\end{array}$ & $\begin{array}{l}\text { - Abandon during the Palace } \\
\text { Reconstruction of Xuanzong of Tang } \\
\text { - Serious Destruction } \\
\text { - Backfill after Archaeology Excavation }\end{array}$ \\
\hline $\begin{array}{l}\text { No.2 Unknown } \\
\text { Thermae }\end{array}$ & Unknown & $\begin{array}{l}\text { Unknown, } \\
\text { Probably as Early } \\
\text { as the Northern } \\
\text { Wei Period }\end{array}$ & Slate Masonry & Bottom: Stone Masonry & $\begin{array}{l}\text { Unknown Approach with } \\
\text { Pottery Pipes }\end{array}$ & Brickwork Open Channel & $\begin{array}{l}\text { - Abandon during the Palace } \\
\text { Reconstruction of Xuanzong of Tang } \\
\text { - Serious Destruction } \\
\text { - Backfill after Archaeology Excavation }\end{array}$ \\
\hline $\begin{array}{l}\text { Mt. Li Thermae } \\
\text { of Qin and Han }\end{array}$ & $\begin{array}{l}\text { Emperors of Qin } \\
\text { and Han }\end{array}$ & $\begin{array}{l}\text { Emperor Qin Shi } \\
\text { Huang }\end{array}$ & $\begin{array}{l}\text { Wall: Brick } \\
\text { Bottom: Slate } \\
\text { Masonry }\end{array}$ & $\begin{array}{l}\text { Wall: Stone Masonry + } \\
\text { Rammed Earth } \\
\text { Bottom: Brick + Rammed } \\
\text { Earth }\end{array}$ & Masonry Open Channel & $\begin{array}{l}\text { Masonry Open Channel, with Slate Weir for } \\
\text { Water Level Control }\end{array}$ & - Backfill after Archaeology Excavation \\
\hline $\begin{array}{l}\text { Small Thermae } \\
\text { (Pear Orchard) }\end{array}$ & $\begin{array}{l}\text { Artists of Pear } \\
\text { Orchard }\end{array}$ & $\begin{array}{c}\text { Emperor } \\
\text { Xuanzong of Tang }\end{array}$ & Slate Masonry & Bottom: Rammed Earth & $\begin{array}{l}\text { Male-female Pottery Pipes } \\
\text { beneath, Hot Spring Gushing } \\
\text { from the Bottom of a Wall }\end{array}$ & $\begin{array}{l}\text { Sinkhole at the Bottom of a Wall, Connected } \\
\text { with Underground Masonry Conduit, with } \\
\text { Slate Weir for Water Level Control }\end{array}$ & - Plan to Restore \\
\hline
\end{tabular}




\section{References}

1. Ureche-Trifu, C. Minimal Intervention and Decision Making in Conserving the Built Heritage. Ph.D. Thesis, Carleton University, Ottawa, ON, USA, 2013.

2. Poulios, I. Moving beyond a values-based approach to heritage conservation. Conserv. Manag. Archaeol. Sites 2010, 12, 170-185. [CrossRef]

3. Smith, L. Uses of Heritage; Routledge, Taylor \& Francis Group: London, UK; New York, NY, USA, 2006.

4. Ashworth, G. From history to heritage-From heritage to identity. In Building a New Heritage: Tourism, Culture and Identity in the New Europe; Routledge: London, UK, 2013; pp. 13-30.

5. Byrne, D.; Brayshaw, H.; Ireland, T. Social Significance: A Discussion Paper; NSW National Parks and Wildlife Service: New South Wales, Australian, 2003.

6. Secter, M. The yin-yang system of ancient china: The yijing-book of changes as a pragmatic metaphor for change theory. J. Interdiscip. Cross-Cult. Stud. 1998, 1, 85-106.

7. Čarnogurská, M. Original ontological roots of ancient chinese philosophy. Asian Philos. 1998, 8, $203-213$. [CrossRef]

8. Schwartz, B.I. The World of Thought in Ancient China; Harvard University Press: Cambridge, MA, USA, 2009.

9. Li, C. The ideal of harmony in ancient chinese and greek philosophy. Dao 2008, 7, 81-98. [CrossRef]

10. Smith, L. Intangible heritage: A challenge to the authorised heritage discourse? Rev. D'etnol. Catalunya 2015, 40, 133-142.

11. Waterton, E.; Smith, L. The recognition and misrecognition of community heritage. Int. J. Herit. Stud. 2010, 16, 4-15. [CrossRef]

12. Brockwell, S.; O'Connor, S.; Byrne, D. Transcending the Culture-Nature Divide in Cultural Heritage: Views from the Asia-Pacific Region; ANU Press: Canberra, Australia, 2013.

13. Taylor, K.; Lennon, J. Cultural landscapes: A bridge between culture and nature? Int. J. Herit. Stud. 2011, 17, 537-554. [CrossRef]

14. Winter, T. Beyond eurocentrism? Heritage conservation and the politics of difference. Int. J. Herit. Stud. 2014, 20, 123-137. [CrossRef]

15. Zhang, Y.; Wu, Z. Heritage conservation and urban landscaping of ancient pan pool neighborhood, qufu: A historical and indigenous perspective. Conserv. Sci. Cult. Herit. 2014, 14, 15.

16. Chen, X.; Wu, J. Sustainable landscape architecture: Implications of the chinese philosophy of "unity of man with nature" and beyond. J. Landsc. Ecol. 2009, 24, 1015-1026. [CrossRef]

17. Liu, H.; Yeh, C.-K.; Chick, G.E.; Zinn, H.C. An exploration of meanings of leisure: A chinese perspective. J. Leis. Sci. 2008, 30, 482-488. [CrossRef]

18. Yun, S.H. An analysis of confucianism's yin-yang harmony with nature and the traditional oppression of women: Implications for social work practice. J. Soc. Work 2013, 13, 582-598. [CrossRef]

19. King, T.F.; Kendall-Miller, H. Environmental reviews and case studies: Indigenous traditional cultural places in environmental impact assessment: The case of the ch'u'itnu watershed. Environ. Pract. 2016, 18, 180-183. [CrossRef]

20. Ashworth, G.J. Guiding the Arrow of Time into the Target of Space: Heritage Planning as the Contemporary Uses of the Past; Geo Pers: Groningen, The Netherlands, 1994.

21. Ashworth, G. Preservation, conservation and heritage: Approaches to the past in the present through the built environment. Asian Anthropol. 2011, 10,1-18. [CrossRef]

22. Merriam, S.B.; Tisdell, E.J. Qualitative Research: A Guide to Design and Implementation; John Wiley \& Sons: Hoboken, NJ, USA, 2015.

23. Johansson, R. On case study methodology. Open House Int. 2007, 32, 48.

24. Yin, R.K.; Nilsson, B. Fallstudier: Design och Genomförande; Liber: Dublin, Ireland, 2007.

25. Jokilehto, J. History of Architectural Conservation; Routledge: London, UK, 2007.

26. Taylor, K. Cultural heritage management: A possible role for charters and principles in asia. Int. J. Herit. Stud. 2004, 10, 417-433. [CrossRef]

27. Taylor, K. Cultural landscapes and asia: Reconciling international and southeast asian regional values. Landsc. Res. 2009, 34, 7-31. [CrossRef]

28. Taylor, K.; Altenburg, K. Cultural landscapes in asia-pacific: Potential for filling world heritage gaps. Int. J. Herit. Stud. 2006, 12, 267-282. [CrossRef] 
29. Pollock-Ellwand, N.; Miyamoto, M.; Kano, Y.; Yokohari, M. Commerce and conservation: An asian approach to an enduring landscape, ohmi-hachiman, japan. Int. J. Herit. Stud. 2009, 15, 3-23. [CrossRef]

30. ICOMOS. The Nara Document on Authenticity. In Proceedings of the Nara Conference on Authenticity in Relation to the World Heritage Convention, in Cooperation with UNESCO, ICCROM and ICOMOS, Phuket, Thailand, 1-6 November 1994.

31. Convention, W.H. World heritage, culture-nature links. In Proceedings of the World Heritage Convention, Bonn, Germany, 28 June-8 July 2015; Volume 75.

32. Chen, O.; Han, D. A participatory multiple criteria decision analysis to tackle a complex environmental problem involving cultural water heritage and nature. Water 2018, 10, 1785. [CrossRef]

33. D'Ayala, D.; Wang, H. Conservation practice of chinese timber structures: 'No originality to be changed'or 'conserve as found'. J. Archit. Conserv. 2006, 12, 7-26. [CrossRef]

34. Zhu, G. China's architectural heritage conservation movement. Front. Archit. Res. 2012, 1, 10-22. [CrossRef]

35. Zhang, $S$. The heritage practices in a chinese historic neighbourhood: The manifestation of traditional feng shui in langzhong, china. Int. J. Herit. Stud. 2018, 24, 531-546. [CrossRef]

36. Wu, Z. Let fragments speak for themselves: Vernacular heritage, emptiness and confucian discourse of narrating the past. Int. J. Herit. Stud. 2014, 20, 851-865. [CrossRef]

37. Zhiqin, C. For whom to conserve intangible cultural heritage: The dislocated agency of folk belief practitioners and the reproduction of local culture. Asian Ethnol. 2015, 74, 307.

38. Qian, F. China's burra charter: The formation and implementation of the china principles. Int. J. Herit. Stud. 2007, 13, 255-264. [CrossRef]

39. Zhu, Y. Cultural effects of authenticity: Contested heritage practices in china. Int. J. Herit. Stud. 2015, 21, 594-608. [CrossRef]

40. Kwanda, T. Western conservation theoryand the asian context: The different roots of conservation. Int. J. Cult. Prop. 2009, 13, 215.

41. Akagawa, N. Rethinking the global heritage discourse-overcoming 'east'and 'west'? Int. J. Herit. Stud. 2016, 22, 14-25. [CrossRef]

42. $\mathrm{Xu}, \mathrm{X} . \mathrm{-L}$. A tentative study on emperors bathing culture in huaqing pool in lintong. Tangdu J. 2008, 1, 15-18.

43. Luo, X.; Liao, C. The first-stage excavation report of thermae heritage of tang huaqing pool. Cult. Relics 1990, 5, 10-20.

44. Luo, X. The second-stage excavation report of thermae heritage of tang huaqing pool. Cult. Relics 1991, 9, $1-14$.

45. Luo, X. Excavation of the qin-han bath pool at lishan. Cult. Relics 1996, 11, 4-25.

46. Luo, X. Excavation of the living quarter of royal musicians and bathroom in the huaqing palace of the tang dynasty. Cult. Relics 1999, 3, 25-42.

47. Luo, X. Tang Hua Qing Gong; Wen Wu Chu Ban She: Beijing, China, 1998.

48. Wu, Q.-L. Mean harmony, natural harmony and inner harmony-the aesthetic shaping of confucianists chan buddhism taoist to traditional architecture. J. Honghe Univ. 2013, 11, 112-115.

49. Marafa, L. Integrating natural and cultural heritage: The advantage of feng shui landscape resources. Int. J. Herit. Stud. 2003, 9, 307-323. [CrossRef]

50. Minqiu Song, Y.B. Chang'an zhi: Fu chang'an zhi tu; Zhonghua Shuju: Taipei, Taiwan, 1991.

51. Hiers, G.; Rose, C. Lead in building and contruction. J. Ind. Eng. Chem. 1935, 27, 1133-1135. [CrossRef]

52. Shiping, H. The earthquake-resistant properties of chinese traditional architecture. J. Earthq. Spectra. 1991, 7, 355-389. [CrossRef]

53. Schafer, E.H. The development of bathing customs in ancient and medieval china and the history of the floriate clear palace. J. Am. Orient. Soc. 1956, 76, 57-82. [CrossRef]

54. Kang, W.G. Comparison of bathing rituals of ancient rome and china of qin. J. Fuyang Teach. Coll. Soc. Sci. 2005, 1, 126-127.

55. Lin, Y. Select the Train of Thought of the Almance of Day to Analyse and Study-Regard "Making by Imperial Order Association's Discipline and Distinguishing the Square Book" as the Centre; Nanhua University: Dalin, Taiwan, 2007.

56. You, X.T. The Development and Social Interaction in Bathhouses in Ming and Qing Dynasty; National Tsing Hua University: Hsinchu, Taiwan, 2010. 
57. Weber, M. The Religion of India: The Sociology of Hinduism and Buddhism; Martindale: New Providence, NJ, USA, 1958.

58. Clarke, J.J. Oriental Enlightenment; Routledge: London, UK; New York, NY, USA, 1997; pp. 112-129.

59. Peleggi, M. The unbearable impermanence of things: Reflections on buddhism, cultural memory and heritage conservation. In Routledge Handbook of Heritage in Asia; Routledge: London, UK, 2012; pp. 55-68.

60. Simons, R. Feng Shui: Step by Step; Crown Trade: New York, NY, USA, 1996.

61. Hwangbo, A.B. A new millennium and feng shui. J. Archit. 1999, 4, 191-198. [CrossRef]

62. Mak, M.Y.; Ng, S.T. The art and science of feng shui-A study on architects' perception. Build. Environ. 2005, 40, 427-434. [CrossRef]

63. Han, K.-T. Traditional chinese site selection-feng shui: An evolutionary/ecological perspective. J. Cult. Geogr. 2001, 19, 75-96. [CrossRef]

64. Kiker, G.A.; Bridges, T.S.; Varghese, A.; Seager, T.P.; Linkov, I. Application of multicriteria decision analysis in environmental decision making. Integr. Environ. Assess. Manag. 2005, 1, 95-108. [CrossRef] [PubMed]

65. Weber, M.; Gerth, H. The Religion of China. Confucianism and Taoism. Philosophy. 1953, 28, 187-189.

66. Li, C. The Confucian Philosophy of Harmony; Routledge: London, UK, 2013; Volume 10.

67. Wang, H.; Wu, X.; Dou, F.; Xie, J.; Wang, Y. The culture spirit of chinese traditional architecture influenced by confucian. J. Yunnan Agric. Univ. (Soc. Sci.) 2016, 10, 41-45.

68. Xuecai, Y. Confucius' thoughts about cultural heritage protection. J. Huazhong Archit. 2008, 4, 10.

69. Xuecai, Y. Tradition of architectural heritage conservation in china. J. Huazhong Archit. 2008, 2, 21.

70. Xuecai, Y. Brief narrative on protection practice of chinese ancient heritage. J. Huazhong Archit. 2008, 3, 15.

71. Mills, J.E. Spiritual Landscapes: A Comparative Study of Burial Mound Sites in the Upper Mississippi River Basin and the Practice of Feng Shui in East Asia; University of Minnesota: Minneapolis, MN, USA, 1992.

72. $\mathrm{Xu}, \mathrm{R}$. The application of i culture in residential construction. J. Yanan Univ. 2014, 36, 27-31.

73. Lin, Y.-C.; Wu, T.-C.; Hsu, M.-F. A case study of liao chih-te's lóh-ko technique in tainan. J. Folk Art 2009, 166, 141-184.

74. Lowenthal, D.; Binney, M. Our Past before Us: Why do We Save it? T. Smith: London, UK, 1981. 